\title{
Sixty Years Later: Africa's Stalled Decolonization
}

\author{
I. Taylor \\ University of St Andrews, Scotland, United Kingdom
}

\begin{abstract}
The year 1960 marked the moment when the number of nominally independent African countries on the continent rose from nine to twenty-six and is a symbolic indicator of when Africa began to emerge from the days of European colonization. However, from the beginning, very few of Africa's leaders sought to reorganize the continent's economic structures and did virtually nothing to question its external exchange relations. Preferring to play the role of compradors, most preferred to stay wedded to their former colonial masters.

Consequently, sixty years after the Year of Africa, most African countries continue to be entrenched in a set of connections that fit well with Kwame Nkrumah's description of neocolonialism. This neocolonialism has a highly resilient material base which continues to maintain the continent in its subordinate global status and which perpetuates its underdevelopment. Sustainable growth and development in Africa continues to be blocked by the domination of external economies. African countries remain constrained from accumulating the necessary capital for auto-centric growth since the surplus is transferred overseas. Asymmetrical economic relationships are embodied by the continued supremacy of the core over Africa, something intrinsic to capitalism.

Unequal exchange, the transfer of surplus i.e. the continued looting of Africa by its elites and their foreign associates, means that the dreams and aspirations of 1960, for the majority of Africans at least, have been frustrated.

Key words: Africa, underdevelopment, neocolonialism, decolonization, P. Baran, K. Marx, V. Lenin
\end{abstract}

For citation: Taylor, I. (2020). Sixty Years Later: Africa's Stalled Decolonization. Vestnik RUDN. International Relations, 19 (4), 39-53. DOI: 10.22363/2313-0660-2020-20-1-39-53

Научная статья

\section{0 лет спустя: незавершенная деколонизация Африки}

\author{
Я. Тэйлор \\ Университет Сент-Эндрюс, Шотландия, Великобритания
}

1960 год, ознаменованный тем, что число формально независимых африканских стран на континенте возросло с 9 до 26, стал символом наступления новой эпохи - освобождения Африки от европейской колонизации. Однако с самого начала очень немногие африканские лидеры стремились по-настоящему реорганизовать экономические модели и практически не ставили под сомнение внешние экономические отношения африканских стран. Они предпочитали играть роль компрадоров, оставаясь преданными своим бывшим колониальным хозяевам.

Соответственно, спустя 60 лет после Года Африки большинство африканских стран по-прежнему укоренены в системе отношений, которая хорошо соответствует определению неоколониализма в трактовке Кваме Нкрумы. Этот неоколониализм сохраняет устойчивую материальную базу, что позволяет поддерживать подчиненный статус континента в мире и его отсталость. Устойчивый рост и развитие в Африке нивелируется доминированием экономической модели, ориентированной на экспорт. Африканские страны все также ограничены в накоплении необходимого капитала для обеспечения эндогенного роста, поскольку основные доходы переводятся за границу.

(C) Taylor I., 2020

This work is licensed under a Creative Commons Attribution 4.0 International License.

https://creativecommons.org/licenses/by/4.0/ 
Асимметричные экономические отношения воплощаются в непрекращающемся превосходстве стран мирового ядра над Африкой, что внутренне присуще капитализму.

Неравноценный обмен, вывод доходов за рубеж, то есть продолжающееся разграбление Африки ее элитами и их иностранными партнерами означает, что мечты и чаяния 1960 г., по крайней мере для большинства африканцев, остались нереализованными.

Ключевые слова: Африка, отсталость, неоколониализм, деколонизация, П. Баран, К. Маркс, В.И. Ленин

Для цитирования: Taylor I. Sixty Years Later: Africa's Stalled Decolonization // Вестник Российского университета дружбы народов. Серия: Международные отношения. 2020. Т. 20. № 1. C. 39-53. DOI: 10.22363/2313-0660-2020-20-1-39-53

\section{Introduction}

Sixty years ago was the Year of Africa, when the number of nominally independent countries on the continent rose from 9 (with a combined population of 95 million) to 26 (with a population of 180 million). Regaining their independence from Belgium, France and the United Kingdom, these countries entered the global stage with varying degrees of confidence and had wildly different economic and political agendas. From Day One, comprador elites in many of these states (and in particular, the Francophone ones) resisted any wholesale restructuring of the economic and political ties that had been introduced during the colonial period, preferring to stay wedded to their former masters. Indeed, an entire edifice was constructed in the former French zone, which early on was recognized as being neocolonial in nature [Amin 1973]. Captured in the terms le village franco-africain [Glaser, Smith 1992] or la Françafrique [Vershave 2003] highly personalized networks underpinned relations (and continue to do so), which guarantee access to natural resources and markets in Africa for French interests. The French are not unique in this regard, albeit perhaps most brazen.

Most of Africa continues to be embedded in a set of associations that fit well with Kwame Nkrumah's description of neocolonialism, whereby 'the State which is subject to it is, in theory, independent and has all the outward trappings of international sovereignty. In reality its economic system and thus its political policy is directed from outside' [Nkrumah 1965]. On the basis of this description, neocolonialism is a system of domination and exploitation, invested and maintained by the former colonial power in which economic, financial and military instruments work for keeping in power well-disposed leaders and maintaining favourable policies which procure economic and financial advantages. The saliency of neocolonialism is that it remains a powerful analytical category to understand contemporary Africa's political economy. This neocolonialism has a highly resilient material base which continues to maintain the continent in its subordinate global status and which perpetuates its underdevelopment. It is the argument of this article that such conditions mean that Africa is still waiting, sixty years later, for true independence.

\section{The Mechanics of Underdevelopment}

Paul Baran's work on the actual and potential surplus that is encumbered from being deployed in the underdeveloped economies lays a basis for understanding how and why Africa's developments has been retarded, despite the high hopes of the 1960s. For Baran, actual economic surplus is 'the difference between society's actual current output and its actual current consumption', something identical with current savings or accumulation. Potential economic surplus is 'the difference between the output that could be produced in a given natural and technological environment with the help of employable productive resources, and what might be regarded as essential consumption' [Baran 1957: 22]. It is the process of unequal exchange (which includes declining terms of trade) which is the key to how the periphery is drained of surplus value.

The foundations for this were, inter alia, firstly, the colonial economies' forced integration into global capitalism in a subservient arrangement so that the colonial economy was defined not by the needs of the native populations, but by the 
demands and concerns of the economy of the metropole and its ruling class, often under monopoly conditions. The underlying logic and driving force of capitalism and capital is the accumulation of profits; in the words of Marx, the 'boundless drive for enrichment' and the 'passionate chase after value' [Marx 1867/1977: 151]. Certainly, it is inherent in capitalist production to endeavour for unrestrained expansion. Under precapitalist economic systems production was everywhere continued in the same arrangement and on the same scale as before; under capitalism, however, the resumption in the same form becomes impracticable and unrestricted expansion and continuous progress, emerges as the law of production [Lenin 1897/1981]. It is this 'dynamic of endless accumulation' and quest for 'accumulation for its own sake' [Brenner 2006: 80] that makes it such a pioneering and productive economic system, albeit intrinsically and pitilessly exploitative.

Exportation and importation if they are a foreign monopoly, yield profits which do not engender generalised domestic income and employment, but produce incomes and employment abroad. This is a drain on the postcolonial countries: "Profits derived from operations in underdeveloped countries have gone to a large extent to finance investment in highly developed parts of the world. Thus while there have been vast differences among underdeveloped countries with regard to the amounts of profits ploughed back in their economies or withdrawn by foreign investors, the underdeveloped world as a whole has continually shipped a large part of its economic surplus to more advanced countries on account of interest and dividends" [Baran 1957: 325].

A key barrier to Africa then is that the actual economic surplus invested in productive activities is lower than the potential economic surplus [Baran 1957: 375]. It is the way in which potential economic surplus is utilized that is problematic in that this is soaked up by various kinds of excess consumption of the ruling elites, by the inclination to hoard at home and abroad, by the continuance of huge and unproductive bureaucracies and expensive military budgets [Baran 1957: 376f].
In addition, of course, a considerable share of this potential surplus is taken out by foreign capital. Under monopoly capitalism, with its increasing concentration and centralization of capital, commercial and technological dualism between transnational corporations and smaller producers deepens. Utilising the super-exploitation of labour in the periphery, price manipulation and "imperialist rent" springing from the command of strategic commodities [Higginbottom 2014], leads to a transfer of surplus from the peripheral economies to the core in the shape of massive profits. Unequal exchange accounts for the diversity in profit rates between different national capitals and particularly between core and periphery. Indeed, a calculation of UNCTAD and Global Development Finance statistics shows that the underdeveloped world is where profits are the highest. Profit remittances from sub-Saharan Africa totalled USD $32.1 \mathrm{bln}$ in 2010 , which was equivalent to $80 \%$ of foreign direct investments (FDI) inflows and is significantly higher than in other regions (Table 1).

Table 1

\section{Profit Remittances as a Proportion of FDI Flows by Region}

\begin{tabular}{|l|c|c|}
\hline \multicolumn{1}{|c|}{ Region } & $\begin{array}{c}\text { 2001-2005 } \\
\text { average, \% }\end{array}$ & $\begin{array}{c}\mathbf{2 0 0 6 - 2 0 1 0} \\
\text { average, \% }\end{array}$ \\
\hline Sub-Saharan Africa & 59.9 & 83.5 \\
\hline $\begin{array}{l}\text { Latin America } \\
\text { and Caribbean }\end{array}$ & 41.4 & 67.8 \\
\hline South Asia & 59.3 & 45.1 \\
\hline $\begin{array}{l}\text { East Asia } \\
\text { and Pacific }\end{array}$ & 32.3 & 38.6 \\
\hline $\begin{array}{l}\text { Europe and Central } \\
\text { Asia }\end{array}$ & 4.3 & 12.9 \\
\hline
\end{tabular}

Source: Global Humanitarian Assistance (GHA) Report 2012 // Development Initiatives. 2012. P. 83. URL: $\quad$ https://www.alnap.org/help-library/globalhumanitarian-assistance-gha-report-2012 (accessed: 02.01.2020).

Furthermore, most FDI into sub-Saharan Africa is capital intensive and creates minimal employment: in 2009 and 2010 FDI inflows created on average only 119 jobs per one million people, which compares unfavourably the worldwide average of 315 direct jobs per one million people. This is because the bulk of FDI 
flows to Africa are directed towards investments in two sectors: coal, oil and natural gas; and metals. Indeed, despite accounting for $47 \%$ of total FDI to Africa over 2006-2011, the coal, oil and natural gas sector accounted for only $7 \%$ of total jobs created by FDI ${ }^{1}$. The values created in the production of exports from the periphery cannot be measured by the prices received for them as these values and prices diverge, thus constituting a flow of value from the peripheral nations.

From this scenario, unequal exchange and disarticulation has resulted. With regard to Africa, Samir Amin [Amin 1974; 1976] has demonstrated that a dependency on foreign capital investments has caused structural distortions of the economies of the continent. For Africa, problematically the economic structures which emerged from the colonial period as a result of the world division of labour distorted the continent in such a way as to create obstacles to development [Amin 1974]. Amin in this respect discusses articulated and disarticulated economies. Articulated economies are those that possess multiple sectors interrelated to each other so that development in one sector stimulates development in another sector. This situation characterises developed economies. On the other hand, disarticulated economies refer to underdeveloped nations where economic sectors are not closely interrelated. Hence, development in one sector is unable to stimulate development in the other sector [Amin 1974]. As Issa Shivji notes, structural disarticulation is where Africa exhibits a 'disarticulation between the structure of production and the structure of consumption. What is produced is not consumed and what is consumed is not produced' [Shivji 2009: 59]. Rather, the economies are orientated outwards: "One finds within each colony the same disjunction, the same disaggregation of the constituent parts of a colonized economy. Instead, the linkages are with the metropolitan economy, and are determined exclusively by the latter in its own interest-an interest which proves

\footnotetext{
${ }^{1}$ Global Humanitarian Assistance (GHA) Report 2012 // Development Initiatives. 2012. URL: https://www.alnap. org/help-library/global-humanitarian-assistance-gha-report -2012 (accessed: 02.01.2020).
}

incompatible with the independence and any real development of the Third World" [Rodney 1972/2018: 29-30].

This contradiction is at the heart of the international division of labour whereby the core produced high technology, high productivity finished products while the semi-periphery and periphery only generated low technology, low productivity products, primarily raw materials.

Pierre Jalée noted that the process of decolonisation did very little to change this - in fact, it exacerbated the situation: "To sum up, in a period of rapid political decolonisation, the international division of labour which is the beall and end-all of imperialism, far from being modified, has grown sharper: for some, the task of producing raw materials and basic products for export in a raw or semi-raw state and the subhuman living standards that go with it; for others, the factories, industrial expansion, and the concomitant high standard of living" [Jalée 1968: 27].

Remarkably, specialisation within the global economy has been celebrated by mainstream economists as providing the former colonised countries with some form of comparative advantage. However, the Prebisch — Singer thesis fundamentally challenge this view (derived from David Ricardo) and questions whether countries that specialise in particular goods (particularly when they are primary commodities) possess a comparative advantage given the declining terms of trade (note that Baran did not discuss deteriorating terms of trade as of major importance). The key argument of Raúl Prebisch [Prebisch 1950] and Hans Singer [Singer 1950] is that gains from international trade are unequally circulated. While developed nations will benefit from long-term improvements in the terms of trade, this is not the case for the underdeveloped countries. Rather, primary commodity producers instead suffer deterioration in the terms of trade over time [Singer 1950].

As Prebisch noted, the centre produces highlevel manufactured products, while the periphery (because of the colonial experience) concentrates in primary products. These different products face divergent elasticities of demand as primary 
products are price and income inelastic, while manufactured goods have a high income elasticity of demand. As incomes rise in a society, consumer demand for manufactured goods increases but the low price elasticity of demand for primary commodities implies that a reduction in their price will do very little to increase the receipts for underdeveloped countries - and may rather lead to a revenue decrease [Gemmill 1962]. This placed countries in the periphery, such as all African ones, at a perpetual disadvantage, as 'no nation can keep up with others in civilisation if deprived of manufactures, and thereby brought down to be a mere agglomeration of clodhoppers' [Engels 1881/2010: 391].

The difference in elasticities result in a decline in the terms of trade for the periphery over the long-run, which is also to a degree linked to dissimilarities in the level of market power in the centre compared to the periphery [Dosman 2008: 243-244]. The classical Ricardian model is based on perfect competition but this will only (in theory) apply to small peripheral economies where the producers are incapable of manipulating prices on the global market [Ricci 2019].

In contrast, for manufactured products, product differentiation and the power of multinational corporations permits such producers to exercise market power and thus influence global prices. The result is that any benefits from technology in primary commodity production are passed on to the consumer through lower prices while improvements in the terms of trade are captured by the producers in the core via higher revenues. Thus while the market power of the core lets industrialised countries keep hold of the advantages of progress in technology, this is not the case for producers in periphery economies. Thus specialisation in primary commodities to benefit from a supposed comparative advantage will result in any short-terms gains from trade bargained away by the centre [Evans 1976]. Unequal trade, inherent in the imperialist expansion of capitalism, then made international trade a vector for the reproduction of underdevelopment: the creation of world poverty and inequality [Hayter 1981; Terreblanche 2014].
While surplus was generated in the African colonies, its appropriation to the metropole was through the mechanism of unilateral transference. Finally, external domination through the colonial state apparatus meant that the bourgeoisie in the metropole controlled the colonies' social surpluses through the control of the power of the state. Here, it is critical to note that African economies are not undeveloped, which is when resources are not utilised, but rather, underdeveloped, which is when resources are being exploited, but used in a manner which benefits external states and not the state in which the resources are located [Frank 1972]. Competition over resources and markets rather than the "free market" has driven this process, resulting in negative consequences for the populations in the continent, brought on by various dynamics, which includes the resultant lack of diversification into higher value-added economic activities and low human development indicators.

Underdevelopment then is a dynamic process which has now lasted centuries. In general, mainstream development economists view un/underdevelopment (the two terms, although distinct, are usually used interchangeably by such analysts) as the original condition of an economy i.e. prior to the modern era, and is part of an evolutionary progression which - if the correct policies are put in place - will result in capitalist development. The critique of this stance is that this trajectory was applicable only to the core and those economies settled by largescale European immigration. It is not applicable to the periphery and technical claims that it is are based on a level of abstract theorising that evacuates the analysis of any context [Sutcliffe 1971]. As Samir Amin notes: "[T]his definition leads straightaway to an essential error: the underdeveloped countries are seen as being like the 'developed' ones at an earlier stage of their development. In other words, the essential fact is left out, namely, that the underdeveloped countries form part of the world system, that the history of their integration into this system forged their special structure — which thenceforth has nothing in common with what prevailed before 
their integration into the modern world" [Amin 1974: 8].

This course is summarised by Andre Gunder Frank's aphorism, namely the 'the development of underdevelopment', which is the outcome of the capitalist course of action when applied to the peripheries [Frank 1972]. The structures of the underdevelopment process are the core-periphery relationships and the expropriation of the economic surplus from the periphery. Global capitalism then is an integrated arrangement that binds African economies into dominantdominated relations. Analysis of accumulation on a world scale reveals that accumulation occurs to the advantage of the core [Amin 1974]. This accumulation may be either by 'accumulation through expansion' i.e. expanded reproduction and 'accumulation through encroachment' i.e. primitive accumulation [Patnaik 2008].

Contrary to what is commonly perceived, it is not the developed world that supplies capital to Africa, but vice versa. Setting aside the vast amounts drained from Africa through unequal exchange, the continent loses more than $\$ 50$ billion per year in illicit financial outflows as multinational companies (primarily from the core) and their allies in African governments involve themselves in fraudulent schemes to avoid tax payments ${ }^{2}$. As Ranjit Sau details: "The so-called multinational and transnational corporations manipulate their accounts so as to locate profits wherever it is most advantageous to them; and on occasion, usually of course to avoid taxation, they declare low profits in underdeveloped countries regardless of the scale of activities. They overcharge the imports into the Third World country and undercharge the exports therefrom. The resultant unequal exchange of course cannot be theoretically captured in a model of competitive trade. Nevertheless the quantitative significance of the hidden flow due to the malpractice of "transfer

\footnotetext{
${ }^{2}$ Illicit Financial Flows: Report of the High Level Panel on Illicit Financial Flows from Africa Addis Ababa: AU/ECA Conference of Ministers of Finance, Planning and Economic Development // African Union/Economic Commission for Africa. 2015. URL: https://www.uneca. org/sites/default/files/PublicationFiles/iff_main_report_26 feb_en.pdf (accessed: 02.01.2020).
}

pricing' by transnationals can hardly be exaggerated" [Sau 1978: 61].

The extraction of capital alongside the absence of any meaningful industrialisation helps explicate why the broad-based development of Africa is blocked. This was identified early on by Paul Baran analysis of the transfer of surplus from the underdeveloped world to the metropoles under conditions of unequal exchange.

\section{Unequal Exchange}

The theory of unequal exchange essentially outlines how 'Products exported to the periphery are important to the extent [that] the return to labour will be less than what it is at the centre. And it can be less to the extent that society will, by every means - economic and non-economic, be made subject to this new function, i.e. providing cheap labour to the export sector' [Amin 1974: 43]. The wage rate of the dominant sectors in the peripheries-almost entirely oriented towards exportation - is depressed down to the minimal level that economic, social and political circumstances permit. This superexploitation in the mode of production which the periphery exchanges with the centre beyond the initial investment serves as a method of transferring surplus value from the periphery to the centre. This drainage is sufficient to help explicate the blocking of development in the periphery and the increasing divergence between core and periphery.

Unequal exploitation of labour in the core and periphery leads to unequal exchange, which thus causes and reproduces unequal development. Pierre Jalée's summation of this concept is worth quoting at length: "Trade is the vehicle for one imprint form of pillage. We know that the value of a commodity is determined by the amount of labour socially necessary to produce it, and that the value of the labour force is represented by the value of the goods required to maintain and renew it. It is recognised, however, that the value of such goods is infinitely lower in underdeveloped countries, where it is a little more than the "physiological minimum" (the exact amount indispensable for subsistence and work), and that in developed countries it combines a complex of 
individual and social expenditures. It follows that, even if one were to calculate on a basis of equal productivity, which is unreal, African, Asian and South American labour is at a far lower price than that of Europeans and North Americans. To give a concrete instance, if our coffee, cocoa, banana, etc. could be produced in Europe or North America they would be much higher in price. It is generally true that the underdeveloped countries export goods and that are relatively undervalued, while those of the developed world are overvalued. This is known as unequal exchange" [Jalée 1977: 86].

Marx's Capital examined the capitalist type of the value relation, so as to work out how capitalist profits could occur if commodities were sold at their value. Prior to the commodification of labour power, when producers owned their means of production, merchant profits only occurred if traders bought the produce at a cheaper price than what they subsequently retailed them for (the circuit $M-C-M$ ) [Marx 1867/1977: 146]. This of course disturbed the equality of exchanges and thus the law of value. Under the capitalist mode of production however, profits are generated in a different way, in line with the law of value, through retaining a working class whose sole resource is the selling of their labour power and compensating them less than the value of the product that they produce.

The principle of equal exchange is retained as the value of labour power, reflected in remunerations, is what it costs to reproduce it. This is necessary labour: "The value of labour power, like that of every other commodity, is determined by the labour time necessary for the production, and consequently for the reproduction as well, of this specific article as well. In so far as it has value, labour power itself represents nothing more than a definite amount of average social labour which has been incorporated in it. Labour power only exists as a capacity of a living individual; its production presupposed his existence; and therefore the production of labour is dependent upon the worker's reproduction of himself, upon the worker's maintenance" [Marx 1867/1977: 167].
Of course, necessary labour is not where the capitalist extracts his profits. That comes from surplus value, the unpaid labour of the worker that the capitalists extract. The rate of surplus value (or rate of exploitation) is the quantity of time the worker must exert to reproduce his wage, in comparison to the amount of time the worker spends to generating profit for the capitalist through unpaid labour. Typically, capitalists seek to intensify the rate of exploitation by either extending the working day, increasing absolute surplus value and/or by cutting necessary labour time by raising labour productivity, thus heightening the relative surplus value.

As Marx notes, if productivity is increased, this does not result in the shortening of the working day, as the capitalist wishes to generate ever more profits. Rather, "it is only the shortening of the labour-time, necessary for the production of a definite quantity of commodities that is aimed at. The fact that the workman, when the productiveness of his labour has been increased, produces, say 10 times as many commodities as before, and thus spends onetenth as much labour-time on each, by no means prevents him from continuing to work 12 hours as before, nor from producing in those 12 hours 1,200 articles instead of 120. Nay, more, his working day may be prolonged at the same time, so as to make him produce, say 1,400 articles in 14 hours" [Marx 1867/1977: 304].

A third method to raise the rate of exploitation is alluded to by Marx, where surplus labour time can additionally be increased 'by lowering the wages of the labourer below the value of his labour-power' [Marx 1867/1977: 297]. The 'Depression of Wages below the Value of Labour-Power', although not discussed by Marx in any depth, 'belongs in an analysis of competition' [Marx 1894/1986: 235]. In fact, the varying rates of surplus value in different economies and thus between various levels of labour exploitation at national levels is at the heart of unequal exchange. This is superexploitation, which is the basis of the capitalist mode of production in that 'our present social order enables the capitalists to buy the labour power of the worker at its value, but to extract 
from it much more than its value by making the worker work longer than is necessary in order to reproduce the price paid for the labour power' [Engels 1872/2011: 306].

"Unequal exchange" was first coined by Arghiri Emmanuel $[1972 ; 1974 ; 1975]$ to analyse international transfers of value hidden behind ostensible equality in trade. Differences in monetary wages between underdeveloped and developed economies, decided by institutional factors (organised labour power and such like), generate inequality in trade and value transfers from the periphery to the developed centre. Emmanuel argued that the value of commodities when exchanged on the international market is not established in the same fashion as on national markets as labour (unlike capital) is not mobile internationally. Thus there can be no equalization of remunerations among countries similar to the equalization of the rate of profit [Emmanuel 1972: ix]. Unequal exchange then is the result of disequilibrium and it was to investigate disequilibrium conditions in the context of rent generation that Marx introduced in Volume III of Capital the form of regulating market-price or market-price of production [Marx 1894/1986: 146, 458].

Critically, the differences in wages which continue due to the nature of the global capitalist economy are disadvantageous for Africa. In essence, international trade is the exchange of values among state-based economies. These values reflect the labour power utilised to generate commodities and differ from the actual production prices materialised on the international market as the wage level (the determinant of the production prices of commodities) is different in different countries. Wages within the organic composition of capital are an independent variable of the system as per Emmanuel [Sau 1978: 51].

This understanding is why Emmanuel and others deny the mainstream theory of comparative costs derived from Ricardo, which was at the heart of the Prebisch - Singer critique. As per this analysis, Ricardo limits the discussion of international trade to circumstances where participants all gain from the exchange. In contrast, the theory of unequal exchange insists that this idealised notion of international commerce ignores the exploitative nature of trade between core and periphery. As noted, wage levels in different categories of countries are fundamental to Emmanuel's unequal exchange theory. Samir Amin by contrast does not accept the argument that wages are the independent variable. Rather, it is the global capitalist system, including in it the trend of unequal exchange that decides the levels and the dynamic contrast in relative wages in the developed and underdeveloped world [Amin 1977].

According to Amin, it is the exchange of commodities whose production contains wage differentials larger than those of productivity that constitutes unequal exchange. In this articulation is included all non-specifics, including articles produced in pre-capitalist sectors in the peripheries where there is no surplus value or profit as the whole of the net output is consumed by wages. Amin [Amin 1976: 148f] asserts that 'exchange is unequal whenever labour of the same productivity is rewarded at a lower rate in the periphery'. In other words, exchange between an underdeveloped country and a developed country is unequal, if the product of an hour of total (direct and indirect) labour of the poorer country is traded for less than the product of an hour of total labour (direct and indirect) of the richer country. For an exchange to be equal, the wage differential must be the same as the productivity differential. This contrasted with Marx, who regarded wage differentials for the same labour performance as being the consequence of temporary causes that capital and labour mobility would resolve over time. For Amin and others, this was intrinsic to the current stage of capitalism. Transnational corporations' productivity levels invariably exceed those of local firms in Africa and bring this higher productivity with them. They can then take advantage of the lower wages, thus facilitating super-profits.

Samir Amin saw the post-feudal era as being made up of a mercantilist stage, as capitalism developed in the core and exchange relations were begun with pre-capitalist formations; a competitive capitalism stage, which 
lasted throughout the 19th century and was typified by relative equal exchanges between core and periphery, when 'external extension of the capitalist market... was of prime importance as a means for realising surplus value' [Amin 1976: 188] and when the division between the developed and underdeveloped world became quite apparent; and the imperialist stage of monopoly capitalism, which emerged at the start of the 20th century. Monopoly capitalism proper then existed up to 1971, to be followed by global monopoly-finance capital after that [Amin 2008]. Monopoly is essentially the centralisation of capital i.e. the distribution of the means of production in an economy, which is a result of 'the action of the immanent laws of capitalistic production itself, by the centralisation of capital' [Marx 1867/1977: 714]. Indeed, 'The whole development of modern capitalism is advancing towards the large producer ousting the small one' [Lenin 1899/1977: 33].

As Amin noted, 'it [was] from the appearance of monopolies at the centre that unequal exchange between the centre and the periphery... resulted. It [was] the rise of monopolies that... made possible an increasing divergence between the wages at the centre and the periphery, for the same productivity, which in turn explains why exchange can be unequal even though the underdeveloped countries export products of modern high-productivity enterprises' [Amin 1974: 123]. This was when 'a cosmopolitan character to production and consumption' emerged [Marx and Engels 1848/2004: 37]. This period was when wages in the metropoles began to increase alongside productivity, capital became increasingly mobile and the international integration of markets and the rise of monopolies accelerated [Foster 2006]. These dynamics cumulatively created the circumstances in which unequal exchange became blatant, and further development along capitalist lines in the bulk of the periphery became blocked or abnormal [Rweyemamu 1973; 1980]. As A.K. Bagchi noted, 'once contact has taken place with a society which was further along on the capitalist path, the lagging societies could not possibly develop in an autonomous fashion' [Bagchi 1982: 141-142] and this historical fact explains certain congenital and pathological qualities common to the nature of capitalism as it developed in the periphery.

\section{Africa in the International Division of Labour}

At the heart of the unequal exchange thesis is the international division of labour and the unequal specialisation that characterises economies in the developed and underdeveloped world: "Two essential facts... characterize the way world trade has developed in the setting of the capitalist system: (1) the development of trade between advanced countries that are of similar structure, and in which, therefore, the distribution of comparative productivities is similar - a development that seems to be more rapid than that of trade between advanced countries and underdeveloped ones, although the distribution of comparative productivities is more diverse in the latter case; and (2) the successive and varying forms assumed by specialization in the periphery, including its present forms, under which the periphery supplies raw materials that are mostly produced by modern capitalist enterprises with high productivity" [Amin 1976: 148].

While developed countries are technologically advanced and engaged in high valueadded activities, Africa's forcible insertion into the global capitalist system under conditions of colonial plunder and unequal specialisation has meant that 'Inequality in wages, due to historical reasons (the difference between social formations) constitutes the basis of a specialization and a system of international prices that perpetuate... inequality' [Amin 1976: 149]. Lenin noted this phenomenon when he posed the question: "Why is it that 'the price of cereals is lower in countries with a predominance of small farmers than in countries with a capitalist method of production'? The answer is that the peasant presents part of his surplus product as a free gift to society (i.e., to the capitalist class). This lower price [of bread and other agricultural products] is also a result of the poverty of the producers and by no means of the productivity of their labour" [Lenin 1914/1935: $559]$. 
The metropolitan centre prevented the colonies in Africa from accumulating capital domestically through initial primitive accumulation and then later the drain mechanism and, by the turn of the twentieth century, unequal exchange [Anievas, Nişancioğlu 2015]. What capital that was invested from the centre into the continent distorted indigenous economic structures and made them outward-looking and increasingly dependent. Deliberate colonial policies prevented an auto-centred capitalism with foundations in the internal market and what capital that was generated was exported.

\section{Capitalism in Africa}

In his seminal work, The Political Economy of Growth, Paul Baran detailed how the drainage of 'economic surplus' formerly accumulated and presently produced in the periphery would result in a retardation of the primary accumulation rate of capital [Baran 1957]. Baran's central line of enquiry was trying to understand why in backward, peripheral, capitalist countries there had been no development akin to that found in the core capitalist economies and why was it that progress in the peripheral economies had been either sluggish or even absent [Baran 1957: 280 -281]. Baran's analysis was that the type of development found in the core (initially Western Europe) itself and the impact of capitalist penetration of the periphery by the core explained this reality.

The penetration of Western European capital outside of the core took two forms. The first were "settler" colonies as found in North America and Australia, whose capitalism led to eventual autonomous development reliant on domestic demand. Surplus generated in agriculture was reinvested domestically, primarily to produce light manufactured products for consumption and capital goods. Improved agricultural modes of production resulted in elevated labour productivity and a higher return to the farmer, in turn generating a demand for mass consumption merchandise, which promoted industrial growth. The surplus labour force from the agricultural sector (alongside mass immigration) was absorbed into the burgeoning industrial sector, while agricultural exports garnered further capital. Crucially, the significant characteristic of this process was that it was selfcentred-the dynamics were interior to the system. The central determining characteristic of such a self-centred system was the interface between the production of mass consumption products and the production of capital goods and this remains true today [Tschannerl 1976: 6].

The second type of capitalist penetration were "extractive" colonies as found in Africa, Asia and parts of Latin America where larger, more organised indigenous populations (alongside disease) prohibited wholesale settlement by Europeans. In such spaces, the colonising powers engaged in basic plunder and/or extraction that was blatantly unequal, appropriating and taking away fantastic wealth. Thus, the economies of these countries were drained to feed the Industrial Revolution in Europe, while they experienced systemic underdevelopment.

The colonial experience then generated a dual economic structure essentially made up of a modern sector geared to the production of primary products for export, which are purchased cheaply, and a backward sector from which relatively cheap labour underwrites the capitalist sector. The different ways capitalism unfolds in two different spatial categories (centre and periphery) is critical to understanding how development is blocked in most of Africa.

In an analysis of the global accumulation of capital, Samir Amin [1974] outlined two different prototypes, one which was applicable at the centre, the other to dependent development in the peripheries. Development in the capitalist core is typified by economic activities to gratify mass consumerism and the resulting requirements for production merchandise. The mass of the population at the centre buys into this model under a form of a "social contract" which permits the organisation of a (temporally limited) viable socio-economic system at a national level.

How a particular order becomes established and is maintained is central to Antonio Gramsci's notion of hegemony [Gramsci 1971]. This has been summarised as: "By hegemony, Gramsci seems to mean a socio-political 
situation, in his terminology a 'moment', in which the philosophy and practice of a society fuse or are in equilibrium; an order in which a certain way of life and thought is dominant, in which one concept of reality is diffused throughout society in all its institutional and private manifestations, informing with its spirit all taste, morality, customs, religious and political principles, all social relations, particularly in their intellectual and moral connotations. An element of direction and control, not necessarily coercion, is implied" [Williams 1982: 94].

The hegemonic class leads society through its leadership of a complex alliance of social forces and leadership in the sphere of production - a "historic bloc". This is the particular formation of social forces and ideology that gives substance to a historical state [Cox 1987: 409] and is linked to the dominant mode of production: "The production of ideas, of conceptions, of consciousness, is at first directly interwoven with the material activity and the material intercourse of men, the language of real life" [Marx, Engels 1846/2015: 42].

As noted, African economic systems are dominated by exports (mostly primary commodities) and there is minimal linkage of these modes of production to the internal mass markets (structural disarticulation). This fosters stagnation, mounting inequality, dependency in multiple forms and political impotence. This is marginalization in action [Amin 1974: 9]. The essential difference between the core and the periphery is that capitalist productive relations in the core were cultivated on the foundations of expanding the domestic market and draining wealth from the peripheries under conditions of imperialism. The process was, as it were, organic and systematic. Capitalist relations in the periphery however were forcibly imposed from the outside at disadvantageous conditions and methodically underpeopled these spaces, with Africa as an example par excellence [Rodney 1972/2018].

According to Amin, following Baran, sustainable growth and development in the periphery is "blocked" since they are "complementary and dominated" by the industrialised countries [Amin 1976: 288]. African countries are inhibited from accumulating the necessary capital for auto-centric growth since the surplus is transferred-drained-overseas. Thus asymmetrical economic relationships are embodied by the continued domination of the peripheral nations and are intrinsic to capitalism [Khamisi 1981]. The polarisation reproduced by unequal exchange is a fundamental feature of global capitalism and imperialism and has now lasted over five hundred-years [Amin 2003]. However, there have been developments within capitalism that are significant, most notably the rise of monopoly capitalism.

\section{Monopoly Capitalism and the Current Epoch}

Under monopoly capitalism, core-periphery relations under mega corporations have severely reduced the opportunities for new centres to emerge [Baran, Sweezy 1966]. Previously, under conditions of competitive capitalism, new centres could rise and old ones decline in a cyclical fashion. However, under monopoly capitalism, such processes are limited, even if monopoly capitalism itself may undergo qualitative changes through the financialization of accumulation and the relative emergence of some nodal points within the global system (see below).

The nineteenth century saw a new type of imperialism emerge, which lasted until c. 1945. At first competitive industrial capitals contended for supremacy and during this periodization discrete economies competed with one another for trade. By the late century however, a decidedly monopolised form of corporate capitalism under the control of finance capital had developed. Primitive accumulation in the colonies had set the stage for the export of commodities while capital expanded what was increasingly a global market. The growth of monopoly capitalism and its associated financial oligarchy unavoidably engendered the exportation of capital and the division of the world into colonial empires. The decisive feature of imperialism was not merely a consequence of under consumption in the metropoles [Luxemburg 1913/1951], nor simply scientific advances [Hobsbawm 1994], but was 
more specifically the concentration of capital i.e. monopolies [Patnaik 1986].

This concentration of capital changed the nature of Western Europe's expansion globally: "Obviously, concentration also comes about with the annexation of colonies. There was formerly an economic distinction between the colonies and the European peoples-at least, the majority of the latter-the colonies having been drawn into commodity exchange but not into capitalist production. Imperialism changed this. Imperialism is, among other things, the export of capital. Capitalist production is being transplanted to the colonies at an ever increasing rate. They cannot he extricated from dependence on... finance capital" [Lenin 1916/1977: 325].

This period of monopoly capitalism was characterised by core-periphery and interimperialist rivalries and, as Lenin noted, a growing dependency of the periphery on the core. The dynamics unleashed by the stage of capitalism eventually led to two world wars and later, the development of national liberation struggles throughout the colonised world. The inter-imperialist element of the contradiction involved what was essentially a transitional phase of succession vis-à-vis the headship of imperialism, with the United Kingdom eventually submitting to an American-led capitalist world order. However, widespread contradictions between the centres and peripheries regarding political sovereignty also marked this period. Threatening to seriously challenge the status quo, monopoly capital developed a new approach to control the periphery, namely neocolonialism.

Meanwhile, as countries such as Germany and Japan emerged and commenced to contend with American corporations, monopoly capital experienced an evolution to what Amin called 'collective imperialism' [Amin 2003], what was to become a new period of monopoly capitalism where contemporary capitalism is essentially a capitalism of generalized monopolies constituting an integrated system. This structure makes certain that the monopolies extract a monopoly rent collected from the mass of surplus value (converted into profits) that capital extracts from the exploitation of labour power. When and where these monopolies function in the underdeveloped world, this monopoly rent constitutes an imperialist rent. The contemporary capital accumulation process is thus constituted by the intensification of monopolistic/imperialist rent [Amin 2019: 32].

While the United States retained headship, a harmonised system of "global governance" developed with monopolistic management of finance, technology and the world's resources. Consequently, "it is clear that imperialism has not disappeared or even declined; rather, it has changed its form over the past half century. The more classic features (as expressed for example in colonial control and annexations) are less in evidence, while newer features are expressed through international institutions, regulatory architecture and related negotiations. Under this arrangement, the intensification of the internationallisation of production under the auspices of mega corporations (what is conventionally termed 'globalisation') occurred" [Ghosh 2019: 388].

This rapidly increased after the collapse of the actually existing socialist states at the end of the 1980s. Consequently the entire world has been subsumed under its logic. The concurrent reintegration of the Peoples' Republic of China into the global capitalist order has further deepened these processes (see: [Taylor 2017]).

\section{Conclusion}

For the first decades of African independence, the elites in power tried to build their nations, which was essentially a statist project. The political economy of nationbuilding, whether through the agency of the state or state-aided private bourgeoisies, revolved around domesticating the process of capitalistic accumulation. Imperialist hegemony, however, ensured that whatever national bourgeois elements were born were quickly compradorised, re-imposing primitive accumulation. Even the most radical nationalist elites failed to build popular hegemonic blocks that would spearhead the national project. By the 1980s, when imperialism regained the offensive in the form of neo-liberalism, African states were already vulnerable. They quickly capitulated with internal 
compradors seizing the initiative [Shivji 2019: 262]. What has meant is that today: "The new liberalisation differs from the old colonial liberalisation in at least two respects: it has a strategy of improving further the economic position of the Third World rich at the expense of their fellow-citizens, which has materially corrupted the elite of our country [India]; and it has an ideological thrust in terms of wrong theories, which has intellectually suborned the same Third World public figures and intellectuals who were earlier supporters of independent growth, but how now mindlessly parrot the mantra of liberalisation" [Patnaik 2007: 211].

Most African elites today are visionless and corrupt, caring little for their people. Those leaders who have sought to critically interrogate the global system and Africa's place in it have been swiftly dispatched. The careers of Patrice Lumumba, Kwame Nkrumah, Amilcar Cabral, Thomas Sankara, etc. attest to this reality. Thus working in alliance with external interests, the current generation of African leaders continue with strategies that only reproduce Africa's dependent status, its economic underdevelopment and its political condition of neocolonialism and generalised foreign domination. As Thomas Sankara noted, the enemies of the people are both inside and outside of Africa [Sankara 2007: 52]. With the ideas of the "free market" now hegemonic, critical reflection on the current situation within Africa is infrequent and rarely, if ever, goes beyond problem-solving approaches to immediate tribulations. When looking back to the excitement of 1960, this is not what most African peoples had in mind when they uttered the word, 'independence'.

Received / Поступила в редакцию: 08.01.2020 Accepted / Принята к публикации: 30.01.2020

\section{References / Библиографический список}

Amin, S. (1973). Neocolonialism in West Africa. Harmondsworth: Penguin Books.

Amin, S. (1974). Accumulation on a World Scale. New York: Monthly Review Press.

Amin, S. (1976). Unequal Development: An Essay on the Social Formations of Peripheral Capitalism. New York: Monthly Review Press.

Amin, S. (1977). Imperialism and Unequal Development. Sussex: Harvester Press.

Amin, S. (2003). Obsolescent Capitalism: Contemporary Politics and Global Disorder. London: Zed Books.

Amin, S. (2008). "Market Economy" or Oligopoly-Finance Capital. Monthly Review, 59 (11), $51 — 61$.

Amin, S. (2019). The New Imperialist Structure. Monthly Review, 71 (03). DOI: 10.14452/MR-071-03-2019-07 3

Anievas, A. \& Nişancioğlu, K. (2015). How the West Came to Rule: The Geopolitical Origins of Capitalism. London: Pluto Press.

Bagchi, A. (1982). Political Economy of Underdevelopment. Cambridge: Cambridge University Press.

Baran, P. \& Sweezy, P. (1966). Monopoly Capital: An Essay on the American Economic and Social Order. New York: Monthly Review Press.

Baran, P. (1957). The Political Economy of Growth. New York: Monthly Review Press.

Brenner, R. (2006). What Is, and What Is Not, Imperialism? Historical Materialism, 14 (04), 79-105. DOI: $10.1163 / 156920606778982464$

Cox, R. (1987). Production, Power and World Order: Social Forces in the Making of History. New York: Columbia University Press.

Dosman, E. (2008). The Life and Times of Raúl Prebisch, 1901-1986. Montreal: McGill-Queen's University Press.

Emmanuel, A. (1972). Unequal Exchange: A Study of the Imperialism of Trade. New York: Monthly Review Press.

Emmanuel, A. (1974). The Myths of Development Versus "Myths of Underdevelopment". New Left Review, 85, $61-82$.

Emmanuel, A. (1975). Unequal Exchange Revisited. IDS Discussion Paper, 77. Brighton: University of Sussex.

Engels, F. (1872/2011). The Housing Question. In: Marx, K. \& Engels, F. Karl Marx and Frederick Engels Selected Works. Vol. 2. New Delhi: People's Publishing House.

Engels, F. (1881/2010). The Future Results of British Rule in India. In: Marx, K. \& Engels, F. Marx and Engels Collected Works. Vol. 24. London: Lawrence and Wishart.

Evans, D. (1976). Unequal Exchange and Economic Policies: Some Implications of Neo-Ricardian Critique of Theory of Comparative Advantage. Economics and Political Weekly, 11 (5/7), 143-158. 
Foster, J. (2006). Monopoly-Finance Capital. Monthly Review, 58 (07), 1-14.

Frank, A. (1972). The Development of Underdevelopment. In: Cockcroft, J.D., Frank, A.D. \& Johnson, D. (Eds.). Dependence and Underdevelopment. New York: Anchor Books.

Gemmill, R. (1962). Prebisch on Commercial Policy for LDCs. Review of Economics and Statistics, 44 (02), $198-201$.

Ghosh, J. (2019). A Brave New World, or the Same Old Story with New Characters? Development and Change, $50(02), 379-393$.

Glaser, A. \& Smith, S. (1992). Ces messieurs Afrique 1: Le Paris-village du continent noir. Paris: Calmann-Lévy.

Gramsci, A. (1971). Selections from the Prison Notebooks. London: Lawrence and Wishart.

Hayter, T. (1981). The Creation of World Poverty. London: Pluto Press.

Higginbottom, A. (2014). "Imperialist rent" in Practice and Theory. Globalizations, 11 (01), 23-33.

Hobsbawm, E. (1994). The Age of Extremes: The Short Twentieth Century, 1914-1991. London: Michael Joseph.

Jalée, P. (1968). The Pillage of the Third World. New York: Monthly Review Press.

Jalée, P. (1977). How Capitalism Works. New York: Monthly Review Press.

Khamisi, L. (1981). Imperialism Today: A Contribution to the University of Dar es Salaam Debate. Dar es Salaam: Tanzania Publishing House.

Lenin, V. (1897/1981). A Characterisation of Economic Romanticism. Moscow: Progress publ. (In Russian).

Lenin, V. (1899/1977). Our Programme. In: Lenin: Selected Works. Moscow: Progress publ. (In Russian).

Lenin, V. (1914/1935). The Teachings of Karl Marx. In: Burns, E. (Eds.) Handbook of Marxism. London: Victor Gollancz.

Lenin, V. (1916/1977). The Discussion on Self-Determination Summed Up. In: Lenin, V.I. Collected Works. Vol. 22. Moscow: Progress Publishers.

Luxemburg, R. (1913/1951). The Accumulation of Capital. London: Routledge \& Kegan Paul.

Marx, K. \& Engels, F. (1846/2015). The German Ideology. New Delhi: People's Publishing House.

Marx, K. \& Engels, F. (1848/2004). Manifesto of the Communist Party. Beijing: Foreign Languages Press.

Marx, K. (1867/1977). Capital: A Critique of Political Economy. Vol. 1. Moscow: Progress publ. (In Russian).

Marx, K. (1894/1986). Capital: A Critique of Political Economy. Vol. 3. Moscow: Progress publ. (In Russian).

Nkrumah, K. (1965). Neocolonialism: The Last Stage of Imperialism. New York: International Publishers.

Patnaik, P. (1986). Lenin and Imperialism: An Introduction. In: Patnaik, P. (Eds.) Lenin and Imperialism: An Appraisal of Theories and Contemporary Reality. London: Sangam Books.

Patnaik, P. (2008). The Accumulation Process in the Period of Globalisation. Economic \& Political Weekly, 43 (26/27), 108-113. DOI: $10.2307 / 40278907$

Patnaik, U. (2007). The Republic of Hunger and Other Essays. Monmouth: Merlin Press.

Prebisch, R. (1950). The Economic Development of Latin America and its Principal Problems. New York: UN Department for Economic Affairs.

Ricci, A. (2019). Unequal Exchange in the Age of Globalization. Review of Radical Political Economics, 51 (03), 225-245. DOI: $10.1177 / 0486613418773753$

Rodney, W. (1972). Problems of Third World Development: A Discussion of Imperialism and Underdevelopment. Ufahamu, 3 (02), 27-47.

Rodney, W. (1972/2018). How Europe Underdeveloped Africa. London: Verso Books.

Rweyemamu, J. (1973). Underdevelopment and Industrialization in Tanzania. Oxford: Oxford University Press.

Rweyemamu, J. (Eds.). (1980). Industrialization and Income Distribution in Africa. Dakar: CODESRIA.

Sankara, T. (2007). Thomas Sankara Speaks: The Burkina Faso Revolution, 1983-1987. New York: Pathfinder Press.

Sau, R. (1978). Unequal Exchange, Imperialism and Underdevelopment: An Essay on the Political Economy of World Capitalism. Calcutta: Oxford University Press.

Shivji, I. (2009). Accumulation in an African Periphery: A Theoretical Framework. Dar es Salaam: Mkuki na Nyota Publishers.

Shivji, I. (2019). Whither Africa in the Global South? Lessons of Bandung and Pan-Africanism. In: Moyo, S., Jha, P. \& Yeros P. (Eds.). Reclaiming Africa: Scramble and Resistance in the 21st Century. Berlin: Springer. DOI: 10.1007/978-981-10-5840-0

Singer, H. (1950). The Distributions of Gains Between Investing and Borrowing Countries. American Economic Review, 40 (02), 473- 485.

Sutcliffe, R. (1971). Industry and Underdevelopment. London: Addison-Wesley. 
Taylor, I. (2017). Global Governance and Transnationalising Capitalist Hegemony: The Myth of the "Emerging Powers". London: Routledge.

Terreblanche, S. (2014). Western Empires, Christianity and the Inequalities between the West and the Rest. London: Penguin Books.

Tschannerl, G. (1976). Periphery Capitalist Development: A Case Study of the Tanzanian Economy. Utafiti, 1 (01), $5-46$.

Vershave, F.-X. (2003). Francafrique: la plus long scandale de la republique. Paris: Stock.

Williams, G. (1982). Hegemony, War of Position and Political Intervention. In: Showstock-Sassoon, A. (Eds.). Approaches to Gramsci. London: Writers and Readers.

\begin{abstract}
About the author: Ian Taylor - PhD, Professor in International Relations and African Political Economy, University of St Andrews, UK; Extraordinary Professor, University of Stellenbosch, South Africa; Chair Professor, School of International Studies, Renmin University, China (e-mail: ict@st-andrews.ac.uk).
\end{abstract}

Сведения об авторе: Ян Тэйлор - доктор философии, профессор по международным отношениям и африканской политэкономии, Университет Сент-Эндрюс, Великобритания; экстраординарный профессор, Стелленбосский университет, ЮАР; заведующий кафедрой, Школа международных исследований, Китайский народный университет, КНР (e-mail: ict@st-andrews.ac.uk). 